\title{
Disclosures of ESG Misconducts and Market Valuations: Evidence from DAX Companies
}

\author{
Anna Dziadkowiec, Karolina Daszynska-Zygadlo
}

Wroclaw University of Economics and Business

Komandorska st. 118/120, 53-345, Wroclaw, Poland

E-mail.anna.dziadkowiec@ue.wroc.pl; karolina.zygadlo@ue.wroc.pl

cross $^{\text {ref }}$ http://dx.doi.org/10.5755/j01.ee.32.2.25209

Environmental, social and governance (ESG) factors have become an important topic on capital markets amid an increasing interest in responsible investing. Despite this fact, public companies have been involved in a number of ESG misconducts in recent years, which were often against the interests of their stakeholders. In our research, we refer to stakeholder theory in order to show how disclosures of social misconducts against the companies' stakeholders have affected market valuation of listed companies, which we treat as one of the measures of shareholders' wealth. We conduct an event study on 235 ESG misconducts related to DAX companies. The data sample of ESG news was hand collected in a thorough content analysis in the period of 2000-2019. The main findings reveal that investors' reactions were more severe for ESG news released after 2009 than before this date as illustrated by negative and significant cumulative average abnormal returns (CAARs) in different event windows, while before 2009 CAARs were insignificant. We also found out that investors reacted stronger to governance-rather than social or environmental news. Our results provide a guidance for listed companies on how ESG mismanagements might affect their market value, and for investors who intend to incorporate ESG factors in their investment decision processes.

Keywords: Event Study; ESG Misconducts, DAX; Responsible Investing; Corporate Social Responsibility (CSR).

\section{Introduction}

Environmental, social and governance (ESG) factors have attracted an increasing interest of investors and regulators on capital markets. This has been assisted by a growing volume of sustainable investments (GSIA, n.d.) and improving incorporation of ESG factors among asset managers (Berry \& Junkus, 2013; Jansson \& Biel, 2016; Van Duuren et al., 2016; Amel-Zadeh \& Serafeim, 2018). In recent years, companies have engaged in corporate social responsibility (CSR) activities, incentivized by their impacts on companies' image (Virvilaite \& Daubaraite, 2011; Lii \& Lee, 2012), reputation (Yoon et al., 2006), competitive advantages (Juscius \& Snieska, 2008), market value and financials (Preston \& O'Bannon, 1997; Waddock \& Graves, 1997; Al-Tuwaijri et al., 2004; Luo \& Bhattacharya, 2006; Daszynska et al., 2016) as well as risk metrics (Jo \& Na, 2012).

Even though the concept of CSR is well-rooted in investment policies, management practice and scientific research, some companies have not faced up to social responsibilities towards their stakeholders. This also applies to firms from DAX index, which have revealed several major ESG mismanagements in recent years, including emissions scandals, discrimination cases, labour disputes, frauds, tax evasions and money laundering.

The scientific problem of this article is to analyze how disclosures of ESG misconducts have affected market valuations of DAX companies. The aim of the research is to determine how the mismanagements towards companies' stakeholders (e.g. environment, communities, investors, regulators) affect market capitalization of listed companies, which we treat as one the measures of shareholder's wealth. In our research, we investigate how investors reacted to disclosures of ESG misconducts released before and after the global financial crisis of 2007-2008. We find it particularly important for adverse ESG news as negative/exclusionary screening was still the most popular sustainable investing strategy in Europe (GSIA, n.d.) as well as in Germany in 2018 (FNG, 2019).

We contribute to the existing literature in the following ways. Firstly, we conduct the research on up-to-date, unique observations, selected in a thorough content analysis. Secondly, our data sample is multidimensional and covers all ESG subcategories (i.e. environmental, social, governance), which is still rare in the existing papers. Thirdly, we focus on Germany as investors in that country have paid more attention to ESG factors recently, reflected in a significant growth in the volume of sustainability-oriented investment funds' assets (FNG, 2019). The market is also subject to legislative initiatives oriented at sustainable investing, e.g. the European Union Action Plan on Sustainable Finance. In addition, most of the empirical studies cover ESG news from US stocks, whereas research devoted to European markets is still scarce, with samples dating to the pre-crisis period (Kruger, 2015; Capelle-Blancard \& Petit, 2017). Finally, our study provides empirical insights into stakeholder theory (Freeman, 1984) and efficient market hypothesis (Fama et al., 1969).

The research methods used in the paper include comparative analysis of literature, content analysis and econometric modelling, i.e. event study.

The remaining part of the paper is structured as follows. In the section 'Environmental, Social and Governance Factors in Investing', we discuss current status of responsible 
investing. In 'Theoretical Framework and Empirical Research', we survey the existing theoretical and empirical studies on the value creation potential of ESG-oriented management and develop three research hypotheses. Section 'Data Sample and Methodology' describes the research sample along with the methodology, i.e. event study. In 'Results and Discussion', we present the results to finalize the research in the section 'Conclusions'.

\section{Environmental, Social and Governance Factors in Investing}

Investing aimed at generating positive or reducing negative social outcomes is not a new concept, but it has gained a significant traction in recent years. This is reflected in the value of sustainable investments, which reached $\$ 30.7$ trillion globally in 2018, representing a $34 \%$ increase compared to 2016 (GSIA, n.d.). The trend is particularly visible on the German market, where new inflows to sustainable funds were $€ 10 \mathrm{bn}$ in 2018 and sustainable investments accounted for $4.5 \%$ of total investment funds volume in the period (FNG, 2019).

Recent market growth has been coupled with development of different names associated with strategies, which use environmental, social and governance factors in investments, such as socially responsible investment, ethical investment, social investment, responsible investment, sustainability/sustainable investment (Eccles \& Viviers, 2011). In our research, we refer to responsible investing defined as 'investment practices that integrate a consideration of ESG issues with the primary purpose of delivering higher-risk-adjusted financial returns' (Eccles \& Viviers, 2011, p. 401).

Further integration of ESG factors into asset allocation should be enhanced by the ongoing regulatory discussion and international cooperation on this matter. This includes the 17 Sustainable Development Goals set in the United Nations (UN) 2030 Agenda as the UN calls financial industry to 'disclose and incorporate long-term risk into investment decision making' as well as 'implement sustainable investing strategies, scale up green financial instruments, measure and report on impact' (UN, 2019, p. 6). These postulates seem to be addressed at the European Union (EU) level by the EU Action Plan on Sustainable Finance adopted in March 2018, which supports 1) reorientation of capital flows towards sustainable investment, 2) improved management of financial risks stemming from climate change, environmental degradation and social issues, and 3) enhanced transparency and long-termism in financial and economic activity (European Commission, 2018).

In response to investors' increasing demand and prospective regulatory frameworks, asset managers have more often used ESG criteria in the decision making process. Below, we present a review of the ESG diligence in asset management as its adoption and use may be a trigger for market valuations following disclosures of ESG misconducts, which we empirically study in the following parts of this paper.

The existing survey-based literature reveals that the use of non-financial guidelines in the investment process differs with respect to various aspects. Firstly, incorporation of ESG factors might differ across individual ESG dimensions given that $60 \%$ of the surveyed asset managers had detailed instructions on the use of governance factors, compared with $43 \%$ both for environmental and social issues (Van Duuren et $a l ., 2016)$. Relevance and materiality of the news remains an important theme. A study from Amel-Zadeh \& Serafeim (2018) shows that institutional investors continue to consider country of operations, industry and firms' strategy as crucial when they incorporate ESG factors into the investment decision process.

Secondly, there is an evidence that institutional and individual investors have different perception of ESG diligence. The latter focus more on environmental and social issues when they refer to socially responsible investing (Berry \& Junkus, 2013), while the former are incentivised by beliefs about long-term returns of ESG integration (Jansson \& Biel, 2016; Amel-Zadeh \& Serafeim, 2018). Some studies suggest that ESG diligence serves institutional investors rather as a method for mitigating risk than a tool for additional value creation (Przychodzen et al. 2016; Van Duuren et al., 2016). Moreover, the perception of value creation potential of ESG investing differs across countries, e.g. asset managers in the US are less optimistic about the benefits of socially responsible investing than their European counterparts (Van Duuren et al., 2016).

Finally, investment strategies, which incorporate ESG factors, continue to evolve. Investment professionals consider negative screening strategy (the most popular investment strategy which takes into account non-financial measures) as less beneficial for financial returns than positive screening and active ownership (Amel-Zadeh \& Serafeim, 2018), but at the same time, $60 \%$ of fund managers used red flagging in investment, i.e. 'the process of intensively monitoring and/or excluding stocks that are involved with serious environmental, social, or governance controversies or issues' (Van Duuren et al., 2016, p. 529). On a forward looking basis, Amel-Zadeh and Serafeim (2018) found that ESG investment strategies oriented at positive screening and active ownership should gain on importance.

\section{Theoretical Framework and Hypotheses}

ESG misconducts in our research represent mismanagements towards various companies' stakeholders, defined as 'the groups or individuals who can affect or are affected by the achievement of organization's mission' (Freeman, 1984). This includes primary stakeholders in particular, who ensure the company's survival through their continuing participation in its business operations (Freeman, 1984, Clarkson, 1995). These stakeholders involve the public group (e.g. shareholders, investors, employees, customers and suppliers) and providers of infrastructures and markets (e.g. entities, which set laws, regulations, collect taxes and impose any other obligations on corporations) and violation of companies' duties towards this group of stakeholders is captured in our research in press releases classified as social and governance misconducts.

Freeman (1984) and Clarkson (1995) assert that corporate system fails if primary stakeholders withdraw their participation in the company's business. It results from a strong interdependence between a corporation and its primary stakeholder groups. While secondary 
stakeholders are not crucial for the company's survival, they can also harm its business value. The examples of secondary stakeholders include communities, activist groups, media or general public (Freeman, 1984, Clarkson, 1995). Natural environment could also be considered as an organizational stakeholder, although existing papers present contrasting views in that matter (Starik, 1995; Phillips \& Reichart, 2000). In our research we follow the logic of Haigh and Griffiths (2009), who conclude that natural environment is a primary stakeholder (though nontraditional), mainly due to strategic reasons, exhibited by extreme weather events in recent years and their direct impact on companies' operations and financial results. This is one of the reasons why in our research we check also the effects of environmental scandals on companies' market valuation.

Friedman (1970) states that management should focus on maximization of shareholders' wealth, while Freeman (1984) says that the aim is to balance the claims of all the company's stakeholders. Freeman et al. (2007) argue that traditional narratives of capitalism fail to properly address business ethics, oversimplify human beings and focus on capturing- rather than creating value. The authors outline principles for stakeholder capitalism, which is 'based on freedom, rights, and the creation by consent of positive obligations' (Freeman et al., 2017, p. 311). Notably, this term has gone beyond scientific discussion recently, e.g. it has become the theme of Davos Manifesto 2020 in response to the social and environmental challenges, which the global economy has faced in recent years.

Value-creation potential of the firm's corporate social performance has been examined in empirical research for several decades, but the results are rather inconclusive. Friede et al. (2015) presented the main findings of more than 2000 studies published between 1970s and 2015, revealing that $90 \%$ of the papers found a nonnegative relation between corporate social performance and corporate financial performance, with a large share of positive results.

However, most of the existing studies focus on the longterm value creation potential of ESG-oriented management, while its immediate effects on market valuations have been examined less often. In addition, existing papers are usually based on secondary ESG news. This includes studies, which examine how the inclusion in or exclusion from sustainability-oriented indices affects the market valuation in short-term. Based on the findings of the above studies, investors' reactions to these events differ across sustainability indices, e.g. they were insignificant for the FTSE4Good Index (Curran \& Moran, 2007) or Dow Jones Sustainability World Index (Cheung, 2011), and significant for the STOXX Europe Sustainability Index (Daszynska et al., 2014), the Morningstar Socially Responsible Investment Index (Nakai et al., 2013) and the RESPECT Index (Adamska \& Dabrowski, 2016). The findings also reveal that investors' perception of the valueadding/reducing impact of sustainability-oriented management has changed over time. This is illustrated by the contradictory conclusions of Daszynska et al. (2014) and Adamska and Dabrowski (2016), who examined the same index, but over a different time period. Other studies have checked market reactions to corporate social responsibility (CSR) awards and rankings (Doh et al., 2010; Jacobs et al.,
2010; Cordeiro \& Tewari, 2015), which we also treat as secondary ESG information.

It should be noted that all these studies are based on secondary ESG evaluations, therefore they reflect investors' reactions to subjective assessment of sustainability aspects provided by selected financial intermediaries. It is thus difficult to determine if the reactions are triggered by the companies' performance itself or by the informative function of the assessments delivered to investors. This problem has been addressed in studies that focus on the impact of primary ESG news on market valuations, examples of which include environmental disasters and mismanagements (CapelleBlancard \& Laguna, 2010; Xu et al., 2012), layoff announcements (Worrell et al., 1991), bribery and illegalities (Davidson \& Worrell, 1988; Sampath et al., 2018). However, they all cover individual aspects of ESG misconducts selected in different time periods, geographies and with the use of various research methods, which also means that the comparability of the results is limited.

A comprehensive research on individual ESG dimensions was conducted in papers from Capelle-Blancard and Petit (2017) and Kruger (2015). The former revealed that, on average, market value of companies decreases by $0.1 \%$ upon disclosure of negative ESG news whereas positive ESG news do not significantly increase market valuation. These results support the findings of Kruger (2015), who found that investors react strongly negatively to negative ESG news and weakly negatively to positive events. With respect to individual ESG dimensions, Kruger (2015) concluded that market reactions are particularly notable for information related to communities and environment, while findings of Capelle-Blancard and Petit (2017) suggest that the average impact of negative ESG news is similar for environmental-, social- and corporate governance misconducts. Besides, the authors found that stock market reactions have not changed over time. In both papers, samples are limited to US stocks. In the existing literature, there are few articles focused solely on German market, but they only include governance-related issues, such as frauds (Knauer et al., 2015), and tax evasion (Blaufus et al., 2019).

Based on the literature review, we conclude that we contribute to the existing literature by conducting our research for individual ESG subcategories and using up-to-date observations. We perform our analysis for German market, while most of the above studies were carried out on the US stocks and to our best knowledge this is the first research on the topic devoted to the set of 30 largest listed companies in Germany. This paper also contributes to the literature related to the stakeholder-oriented management and efficient market hypothesis.

In consistency with the studies presented in this and the previous section, we have developed the following research hypotheses:

H1: The impact of disclosures of ESG misconducts on companies' market valuation is negative.

H2: The impact of disclosures of ESG misconducts on companies' market valuations is different for different ESG subcategories. 


\section{Data Description and Methodology}

Sample selection and verification process was performed manually. In the first step, we have created a set of key words (Table 1) that has classified a piece of news to each ESG subcategory, i.e. environmental, social and governance (Flammer, 2013; Deak \& Karali, 2014; Davidson \& Worrell, 1988). These key words address the needs of various companies' stakeholders, including primary and secondary stakeholders, as discussed in the section 'Theoretical Framework and Hypotheses'.

The research sample was collected using Newspaper Source provided by EBSCO database, which includes full text for hundreds of the US and other international and regional newspapers. The retrieved news come from business-focused, high-volume, English-language international daily newspapers: Wall Street Journal, New York Times, The Times, and The Washington Post. The selection of news from well-known titles assures that the articles may reach both local and international investors and thus become a trigger for market valuations. The above newspapers cover top stories from capital markets worldwide, which we assume proxies the materiality and importance of the events that they describe. As a result, our study includes only major events as minor and local issues are not covered by the titles.
As a result of the above selection procedure, we have obtained a research sample that included 235 negative ESG news from DAX companies. Notably, we have analyzed firms that were included in the index as at end of April 2019. News items in our research sample were released between January 2000 and May 2019. Governance-related news comprise $71 \%$ of the research sample with 167 pieces of news, followed by social news (41 pieces of news corresponding to $17 \%$ of the research sample) and environmental news (27 pieces of news, $11 \%$ of the research sample). In terms of the data sample concentration, news related to five companies account for $59 \%$ of the sample, with the largest number of news items linked to Deutsche Bank (22\%), Daimler (12\%) and Merck (10\%).

In order to test H1, we have subdivided the sample into news released before 2009 and after 2009, based on the assumption that the global financial crisis 2007-2008 has provoked an increased level of scrutiny towards capital market player, which was at that time also supported by an increasing popularity and growing number of signatories of the United Nations-supported Principles for Responsible Investment launched in 2006. The subsamples include 116 and 119 observations, respectively. In order to test H2, we have subdivided the above subsamples into subsequent ESG subcategories. As a result, we got 25 pieces of news released before 2009 from the social subcategory, 89 from the

Table 1

Key Words for ESG Subcategories

\begin{tabular}{|c|c|c|c|}
\hline Environmental & Social & Governance & Other* \\
\hline $\begin{array}{l}\text { Environmental, contamination, } \\
\text { Environmental Protection Agency, } \\
\text { European Environment Agency, } \\
\text { environmental disaster, ecological } \\
\text { disaster, pollution, spill, leak, } \\
\text { emission, toxic waste, hazardous } \\
\text { waste, radioactive waste }\end{array}$ & $\begin{array}{l}\text { Strike, labour disputes, lay-off, } \\
\text { harassment, discrimination, labour } \\
\text { standard, child labour, human rights }\end{array}$ & $\begin{array}{l}\text { Bribery, corruption, fraud, } \\
\text { embezzlement, laundering, } \\
\text { tax evasion, insider, } \\
\text { whistleblower, cartel }\end{array}$ & $\begin{array}{l}\text { Allegations, accusations, } \\
\text { claims, lawsuit }\end{array}$ \\
\hline
\end{tabular}

Note: For key words from the Other category, a piece of news was assigned to an ESG subcategory based on analysis of the content.

We have used several exclusionary criteria in the selection process to ensure that potential abnormal returns result only from the ESG-related misconducts and reflect the immediate investors' reaction to a piece of news. Firstly, we have excluded all news items for which key words appeared with other significant corporate events, e.g. earnings announcements, acquisitions, CEO successions. Secondly, when a piece of the same news was published in more than one of the above newspapers, we have selected only this press release, which was published first. In the next step, we have analyzed all articles' summaries to assure that all pieces of news are unambiguously negative. Thus, we have excluded all news items, where a key word appeared, but the intention of the company was good (e.g. implementation of policies reducing pollution). We also rejected articles, where a key word and a company's name appeared but the actions were 1) independent from the companies' management or 2) related to some broader market trends and rumors (e.g. an article related to ongoing discussion on implementation of anti-fraud regulations). Finally, we have excluded all articles, which included a retrospective description of an event and presented its background, subsequent actions or/and author's opinion and comments. governance subcategory and 2 news items for environmental misconducts. We do not show results for the latter subsample due to small number of observations. In the same manner, we subdivided the ESG misconducts released after 2009, obtaining 25 environmental-, 16 social- and 78 governance observations (See Tab. 2).

The research methodology is an event study, which represents a systematic examination of the average impact of a certain event on the price of certain type of corporate asset. Event study measures abnormal returns around the event date that were imposed by occurrence of the event. This methodology is grounded in the efficient market hypothesis (Fama et al., 1969), which states that all available information is fully reflected in asset prices. Event studies have been used in a wide range of scientific research in the past, predominantly to examine the impact of financial information on company's valuation, e.g. stock splits and dividend payment (Grinblatt I, 1984), acquisitions and divestitures (Mulherin \& Boone, 2000; Andriuskevicius, 2019) as well as earnings announcements (MacKinley, 1997). Event studies have been historically used to investigate the impact of the inclusion in- or exclusion from- various sustainability indices on market valuations (Curran \& Moran, 2007; Cheung, 2011; 
Daszynska et al., 2014; Adamska \& Dabrowski, 2016). Finally, the event study methodology has been used to investigate the effects of social issues on market valuations, such as environmental disasters (Capelle-Blancard \& Laguna, 2010), strikes (Becker \& Olson, 1986), layoffs (Worrell et al., 1991), or corporate illegalities (Davidson \& Worrell, 1988; Sampath et al., 2018). The latter examples underpin our choice of the research methodology (i.e. event study) given the aim of the research and the fact that the social issues that they refer to correspond with some of the ESG misconducts that we include in our research sample

Event date in our research corresponds to the disclosure of a piece of news in a newspaper. In order to test market reactions to ESG misconducts over different time periods, we have set three event windows: $+/-5$ days from the event date; $+/-10$ days from the event date; +/- 30 days from the event date.

We have calculated abnormal daily returns for each event using market model according to the following formula, where: $R_{i}$, return of a company's stock; $\alpha_{i}$ and $\beta_{i}$ are regression coefficients; $\mathrm{R}_{\mathrm{m}}$, rate of return on the market portfolio; $\varepsilon_{\mathrm{i}}$, error term. Estimation window was set at 90 days, starting from 120 days- and ending 30 days prior to the event (Xu et al., 2012).

$$
\mathrm{R}_{\mathrm{i}}=\alpha_{\mathrm{i}}+\beta_{\mathrm{i}} \mathrm{R}_{\mathrm{m}}+\varepsilon_{\mathrm{i}}
$$

Abnormal returns were determined against a market portfolio, represented by MSCI Germany Index, which covers around $85 \%$ of the equity universe in Germany. Abnormal returns were calculated according to the following formula.

$$
\mathrm{AR}_{\mathrm{it}}=\mathrm{R}_{\mathrm{it}}-\left(\alpha_{\mathrm{i}}+\beta_{\mathrm{i}} \mathrm{R}_{\mathrm{mt}}\right)
$$

In order to test significance of the results, we have applied a non-parametric Generalized Rank Test, which accounts for cross-correlation of returns, serial correlation of returns and event-induced volatility (Kolari \& Pynnonen, 2011). Non-parametric tests are distribution-free (Kolari \& Pynnonen, 2011) and tend to be less sensitive than parametric tests to distributional assumptions. In addition, non-parametric tests are more appropriate for small data samples (Bartholdy et al., 2007), which is a condition applicable for environmental- and social subsamples in our research.

\section{Results and Discussion}

In order to test $\mathrm{H} 1$ and $\mathrm{H} 2$ research hypotheses, event study was run on 1) ESG news for two different periods, i.e. before 2009 and after 2009 and 2) ESG news from each ESG subcategory separately for these two periods. We present the results for average cumulative abnormal returns (CAARs) in Table 2 along with minimum and maximum cumulative abnormal returns (CARs) in different event windows.

For 5-, 10-, and 30-day event windows, CAARs were not statistically significant for negative ESG news items released before 2009, while after 2009 they were negative and significant. There are several factors that could explain the difference in investors' reactions to ESG misconducts released before 2009 and thereafter. Firstly, despite an increased investors' scrutiny after the financial crisis 20072008, companies continue to disclose large-scale scandals against their stakeholders and get penalized for those mismanagements. This has been coupled over recent years with an improving media coverage and faster dissemination of information, which has increased market efficiency (Peress, 2014). Secondly, stronger investors' reactions to ESG misconducts released after 2009 might be attributable to a rising number of fund managers, who have used non-financial criteria in investment decision process, either as a tool for creating value or as a tool for mitigating portfolio risk (Przychodzen et al., 2016; Van Duuren et al., 2016).

Disclosures of ESG misconducts after 2009 triggered negative and significant CAARs in the 5-, 10- and 30-day event window, reducing market valuations by $1.6 \%, 2.1 \%$ and $2.9 \%$, respectively. It is noteworthy that the longer the event window, the stronger the reduction of market valuations, which could suggest that disclosures of further details on the ESG misconduct in subsequent days (e.g. potential financial impacts or at least legal consequences) enable 1) conventional investors to incorporate potential effects of ESG mismanagements into financial forecasts, and 2) responsible investors to evaluate the event according to their investment criteria.

Based on the results described above, we partly confirm our $\mathrm{H} 1$ as the impact of disclosures of ESG misconducts on companies' market valuation was negative and statistically significant for ESG misconducts released after 2009 and negative, but statistically insignificant before this date.

Table 2

\begin{tabular}{|c|c|c|c|c|c|c|c|c|c|c|}
\hline \multirow[b]{2}{*}{ Subsample } & \multirow[b]{2}{*}{$\begin{array}{c}\text { No of } \\
\text { obs. }\end{array}$} & \multicolumn{3}{|c|}{ CAAR } & \multicolumn{3}{|c|}{ Min CAR } & \multicolumn{3}{|c|}{ Max CAR } \\
\hline & & $\begin{array}{c}\text { 5-day } \\
\text { event } \\
\text { window }\end{array}$ & $\begin{array}{c}\text { 10-day } \\
\text { event } \\
\text { window }\end{array}$ & $\begin{array}{c}\text { 30-day } \\
\text { event } \\
\text { window }\end{array}$ & $\begin{array}{c}\text { 5-day } \\
\text { event } \\
\text { window }\end{array}$ & $\begin{array}{c}\text { 10-day } \\
\text { event } \\
\text { window }\end{array}$ & $\begin{array}{c}\text { 30-day } \\
\text { event } \\
\text { window }\end{array}$ & $\begin{array}{c}\text { 5-day } \\
\text { event } \\
\text { window }\end{array}$ & $\begin{array}{c}\text { 10-day } \\
\text { event } \\
\text { window }\end{array}$ & $\begin{array}{c}\text { 30-day } \\
\text { event } \\
\text { window }\end{array}$ \\
\hline Before 2009 & 116 & $0.07 \%$ & $-1.05 \%$ & $0.09 \%$ & $-23.61 \%$ & $-52.40 \%$ & $-61.27 \%$ & $14.34 \%$ & $27.39 \%$ & $62.23 \%$ \\
\hline After 2009 & 119 & $-1.6 \% * *$ & $-2.1 \% * * *$ & $-2.9 \% * * *$ & $-37.52 \%$ & $-34.56 \%$ & $-33.77 \%$ & $18.09 \%$ & $25.67 \%$ & $40.38 \%$ \\
\hline Before 2009 & & & & & & & & & & \\
\hline Environmental & 2 & N/A & N/A & N/A & N/A & N/A & N/A & N/A & N/A & N/A \\
\hline Social & 25 & $0.45 \%$ & $0.27 \%$ & $1.57 \%$ & $-13.53 \%$ & $-23.26 \%$ & $-13.36 \%$ & $11.29 \%$ & $27.39 \%$ & $34.32 \%$ \\
\hline Governance & 89 & $0.02 \%$ & $-1.35 \%$ & $-0.16 \%$ & $-23.61 \%$ & $-52.40 \%$ & $-61.27 \%$ & $14.34 \%$ & $23.48 \%$ & $62.23 \%$ \\
\hline After 2009 & & & & & & & & & & \\
\hline Environmental & 25 & $-1.91 \%$ & $-1.12 \%$ & $-0.82 \%$ & $-37.52 \%$ & $-34.56 \%$ & $-31.52 \%$ & $5.77 \%$ & $9.33 \%$ & $40.38 \%$ \\
\hline Social & 16 & $-2.27 \%$ & $-4.22 \% *$ & $-0.98 \%$ & $-10.26 \%$ & $-19.78 \%$ & $-22.37 \%$ & $5.06 \%$ & $5.26 \%$ & $17.61 \%$ \\
\hline Governance & 78 & $-1.37 \% * *$ & $1.99 \% * * *$ & $3.96 \% * * *$ & $-17.31 \%$ & $-19.40 \%$ & $-33.77 \%$ & $18.09 \%$ & $25.67 \%$ & $29.81 \%$ \\
\hline
\end{tabular}

Results Table

Note: $* * *, * *, *$ represent significance at $1 \%, 5 \%$ and $10 \%$, respectively. 
ESG misconducts released after 2009 have triggered reductions of market valuation in all ESG subcategories (i.e. environmental, social and governance) as illustrated by negative CAARs in the studied event windows. However, CAARs were statistically significant for all event windows only in case of governance-related mismanagements (i.e. CAAR at $-1.37 \%$ for a 5 -day event window, $-1.99 \%$ for a 10 -day event window and $-3.96 \%$ for a 30-day event window) and for social mismanagements, though in the latter case only in the 10-day event window (i.e. CAAR at $4.22 \%)$. CAARs were statistically insignificant for environmental misconducts released after 2009 and in all ESG subcategories before 2009.

With this respect, we note that ESG misconducts are usually more ambiguous for investors than disclosures of purely financial information (such as earnings announcements or dividend declarations) and the potential impact of some types of negative non-financial disclosures on companies' value might be more evident for investors than others. E.g. in our data sample, a vast majority of social issues include such topics as lay-offs, strikes and discrimination trials. While layoffs may have negative social connotations and bring about adverse effects to working environment, they can be evaluated in a positive way by investors who focus on their financial implications. Such evaluation might be even harder for environmental issues as reflected in CAARs that are statistically not significant. In contrast, negative governance news in our sample include issues like bribery, frauds, cartels and fiscal crimes, which are both against social rules and very often have also negative financial impacts, e.g. lead to lawsuits and penalties. In turn, governance news in our sample can be unambiguously classified as value destructive both by investors, who implement responsible investing strategies and by investors, whose decisions are mainly driven by financial criteria.

We also note that more severe investors' reactions after 2009 to governance than to environmental and social misconducts might also reflect some asset management guidelines and policies, which tend to be more detailed for the former ESG subcategory than for the latter (Van Duuren et al., 2016) (See the section 'Environmental, Social and Governance Factors in Investing' for more details).

Consequently, we partly confirm our $\mathrm{H} 2$, which states that the impact of disclosures of ESG misconducts on companies' market valuations is different for different ESG subcategories. In line with our findings, ESG mismanagements had on average a significant negative impact on firm's market value for ESG misconducts released after 2009 for issues classified as governance-related, though with some evidence of significant negative impact of social misconducts as well. This contrasts with the findings of Kruger (2015), who found out that negative ESG news triggered negative and significant investors' reactions when a piece of news was related to mismanagements (towards environment and communities in particular), and CapelleBlancard and Petit (2017), who concluded that investors' reaction is similar irrespective of the type of news. At the same time, we note that the latter examined all ESG issues (i.e. irrespective of their impact on business), while the former focused on materiality ESG events, which was a similar assumption to our research. We believe that our contradictory findings to existing studies might result from the relevance of a piece of information and its potential impact on a company's financials. This is illustrated by a wide range of the obtained CARs for ESG events, irrespective of the period and the ESG subcategory (Tab. 2).

\section{Conclusions}

The aim of the research is to determine how public disclosures of mismanagements towards different stakeholders of listed companies have affected their market capitalization, which we treat as one the measures of shareholder's wealth. Our results show that mismanagements against companies' stakeholders have deteriorated market valuations of the companies listed in the DAX index in the analyzed event windows, though investors' reactions were more severe to ESG misconducts released after 2009, as exhibited by negative and significant CAARs over different event windows after this date. The results also suggest that governance-related issues reduce market valuations to a greater extent than environmental and social issues, with the two latter being value neutral in the studied periods. At the same time, our study suggests that materiality of ESG issues remains an important factor, as reflected in large span between the minimum and maximum CARs in the studied event windows.

This study complements the existing empirical literature on the link between corporate social and financial performance. It also underpins the ongoing discussion on the rationales of incorporating ESG factors into decision making process in practice. Finally, it gives additional insights into the competing theories of shareholders' and stakeholders' capitalism.

It is noteworthy that confounding effects remain an issue in every event study research as there are many other factors that impact market valuations except identified events. Generally, the longer the event window, the greater the risk that such factors will occur (McWilliams \& Siegel, 1997). We address this issue with exclusion criteria (see 'Data and Methodology section'), but we are also aware that we were not able to control for all possible internal and external factors through all event windows used in this paper. Further research could expand the sample to other stock exchanges, including less developed capital markets, in order to check if there are any fundamental differences in investors' behavior with respect to responsible investing.

\section{Acknowledgements}

„This paper was prepared based on research financed from the scientific grant for years 2012-2014 from Polish National Center of Science no 2011/03/B/HS4/05359 entitled "Impact of CSR activities of the firm on its value".

„The project is financed by the Ministry of Science and Higher Education in Poland under the programme „Regional Initiative of Excellence,, 2019-2022 project number 015/RID/2018/19 total funding amount 10721 040,00 PLN” 


\section{References}

Adamska, A., \& Dabrowski, T. J. (2016). Do Investors Appreciate Information about Corporate Social Responsibility? Evidence from the Polish Equity Market. Inzinerine Ekonomika-Engineering Economics, 27(4), $364-372$. https://doi.org/10.5755/j01.ee.27.4.13377

Al-Tuwaijri, S. A., Christensen, T. E., \& Hughes, K. E. (2004). The relations among environmental disclosure, environmental performance, and economic performance: A simultaneous equations approach. Accounting, Organizations and Society, 29 (5/6), 447-471. https://doi.org/10.1016/S0361-3682(03)00032-1

Amel-Zadeh, A., \& Serafeim, G. (2018). Why and How Investors Use ESG Information: Evidence from a Global Survey. Financial Analysts Journal, 74(3), 87-103. https://doi.org/10.2469/faj.v74.n3.2

Andriuskevicius, K. (2019). Comparison of Value Creation through M\&A in European Union. Inzinerine EkonomikaEngineering Economics, 30(2), 187-194. https://doi.org/10.5755/j01.ee.30.1.14306

Bansa, P., \& DesJardine, M. (2014). Business sustainability: It is about time. Strategic Organization, 12(1), 70-78. https://doi.org/10.1177/1476127013520265

Bartholdy, J., Olson, D., \& Peare, P. (2007). Conducting event studies on a small stock exchange. The European Journal of Finance, 13(3), 227-252. https://doi.org/10.1080/13518470600880176

Blaufus, K., Mohlmann, A., \& Schwabe, A. N. (2019). Stock price reactions to news about corporate tax avoidance andevasion. Journal of Economic Psychology, 72, 278-292. https://doi.org/10.1016/j.joep.2019.04.007

Becker, B., \& Olson, C. (1986). The impact of strikes on shareholder equity. Industrial and Labor Relations Review, 39(3), 425-437. https://doi.org/10.2307/2524101

Berry, T., \& Junkus, J. (2013). Socially Responsible Investing: An Investor Perspective. Journal of Business Ethics, 112(4), 707-720. https://doi.org/10.1007/s10551-012-1567-0

Capelle-Blancard, G., \& Laguna, M. A. (2010) How does the stock market respond to chemical disasters? Journal of Environmental Economics and Management, 59(2), 192-205. https://doi.org/10.1016/j.jeem.2009.11.002

Capelle-Blancard, G., \& Petit, A. (2017). Every Little Helps? ESG News and Stock Market Reaction. Journal of Business Ethics, 157(2), 543-565. https://doi.org/10.1007/s10551-017-3667-3

Clarkson M. B. E. (1995). A Stakeholder Framework for Analyzing and Evaluating Corporate Social Performance. The Academy of Management Review, 20(1), 92-117. https://doi.org/10.5465/amr.1995.9503271994

Cordeiro, J. J., \& Tewari, M. (2015). Firm Characteristics, Industry Context, and Investor Reactions to Environmental CSR: A Stakeholder Theory Approach. Journal of Business Ethics, 130, 833-849. https://doi.org/10.1007/s10551014-2115-X

Consolandi, C., Jaiswal-Dale, A., Poggiani, E., \& Vercelli, A., (2009). Global Standards and Ethical Stock Indexes: The Case of the Dow Jones Sustainability Stoxx Index. Journal of Business Ethics, 87(1), $185-197$. https://doi.org/10.1007/s10551-008-9793-1

Curran, M. M., \& Moran, D (2007). Impact of the FTSE4Good Index on firm price: An event study. Journal of Environmental Management, 82(4), 529-537. https://doi.org/10.1016/j.jenvman.2006.02.010

Daszynska-Zygadlo, K., Ryszawska, B., Slonski, T., \& Zawadzki, B. M. (2014). Investors' Reactions for Sustainability Index Inclusion - Is CSR a Good News? Folia Oeconomica, 2(300), 45-60.

Daszynska-Zygadlo K., Slonski, T., \& Zawadzki, B. (2016). The Market Value of CSR Performance Across Sectors. Inzinerine Ekonomika-Engineering Economics, 27(2), 230-238. https://doi.org/10.5755/j01.ee.27.2.13480

Davidson, W., \& Worrell, D. (1988). The impact of announcements of corporate illegalities on shareholder returns. The Academy of Management Journal, 31(1), 195-200. Retrieved from www.jstor.org/stable/256506. https://doi.org/10.2307/256506

Deak, Z., \& Karali, B. (2014). Stock Market Reactions to Environmental News in the Food Industry. Journal of Agricultural and Applied Economics, 46(2), 209-225. https://doi.org/10.1017/S1074070800000742

Doh, J. P., Howton, S. D., \& Howton, S. W. (2010). Does the Market Respond to an Endorsement of Social Responsibility? The Role of Institutions, Information, and Legitimacy. Journal of Management, 36(6), 1461-1485. https://doi.org/10.1177/0149206309337896

Eccles, N. S., \& Viviers, S. (2011). The origins and meanings of names describing investment practices that integrate a consideration of ESG issues in the academic literature. Journal of Business Ethics, 104, 389-402. https://doi.org/10.1007/s10551-011-0917-7

European Commission (2018). Action Plan: Financing Sustainable Growth. COM(2018) 97 final. Brussels.

Fama, E. F., Fisher, L., Jensen, M. C., \& Roll R. (1969). The Adjustment of Stock Price to New Information. International Economic Review, 10(1), 1-21. https://doi.org/10.2307/2525569 
Anna Dziadkowiec, Karolina Daszynska-Zygadlo. Disclosures of ESG Misconducts and Market Valuations: Evidence from ...

Flammer, C. (2013). Corporate social responsibility and shareholder reaction: The environmental awareness of investors. Academy of Management Journal, 56(3), 758-781. https://doi.org/10.5465/amj.2011.0744

Forum Nachhaltige Geldanlagen e.V. (FNG). (2019). Marktbericht Nachhaltige Geldanlagen 2019 - Deutschland, Osterreich und die Schweiz. Retrieved from https://forum-ng.org/images/stories/Publikationen/fngmarktbericht_2019.pdf

Freeman, R. E., Martin, K., \& Parmar, B. (2007). Stakeholder Capitalism. Journal of Business Ethics, 74, 303-314. https://doi.org/10.1007/s10551-007-9517-y

Freeman, R. E. (1984). Strategic Management: A strategic approach. Boston: Pitman

Friede, G., Busch, T., \& Bassen, A. (2015). ESG and financial performance: aggregated evidence from more than 2000 empirical studies. Journal of Sustainable Finance \& Investment, 5(4), 210-233. https://doi.org/10.1080/20430 795.2015.1118917

Friedman, M. (1970). The Social Responsibility of Business is to Increase its Profits. New York Times Magazine, September 13th.

Gilson, C., Hurd, F., \& Wagar, T. (2004). Creating a concession climate: The case of serial downsizers. International Journal of Human Resource Management, 15(6), 1056-1068. https://doi.org/10.1080/09585190410001677313

Global Sustainable Investment Alliance (GSIA). (n.d.). 2018 Global Sustainable Investment Review. Retreived from http://www.gsi-alliance.org/wp-content/uploads/2019/03/GSIR_Review2018.3.28.pdf

Grinblatt, M. S., Masulis, R. W., \& Titman, S. (1984). The valuation effects of stock splits and stock dividends. Journal of Financial Economics, 13(4), 461-490. https://doi.org/10.1016/0304-405X(84)90011-4

Haigh, N., \& Griffiths, A. (2007). The natural environment as a primary stakeholder: the case of climate change. Business Strategy and the Environment, 18(6), 347-359. https://doi.org/10.1002/bse.602

Jansson, M., \& Biel, A. (2011). Motives to engage in sustainable investment: a comparison between institutional and private investors. Sustainable Development, 19(2), 135-142. https://doi.org/10.1002/sd.512

Jacobs, B. W., Singhal, V. R., \& Subramanian, R. (2010). An empirical investigation of environmental performance and the market value of the firm. Journal of Operations Management, 28(5), 430-441. https://doi.org/10.101 6/j.jom.2010.01.001

Jo, H., \& Na, H. (2012). Does CSR Reduce Firm Risk? Evidence from Controversial Industry Sectors. Journal of Business Ethics, 110(4), 441-456. https://doi.org/10.1007/s10551-012-1492-2

Juscius, V., \& Snieska, V. (2008). Influence of corporate social responsibility on competitive abilities of corporations. Inzinerine Ekonomika-Engineering Economics, 58(3), 34-44.

Knauer, C. E., Knauer T., \& Lachmann M. (2015). Fraud characteristics and their effects on shareholder wealth. Journal of Business Economics, 85(9), 1011-1047. https://doi.org/10.1007/s11573-015-0773-5

Kolari, J. W., \& Pynnonen, S. (2011). Nonparametric rank tests for event studies. Journal of Empirical Finance, 18(5), 953-971. https://doi.org/10.1016/j.jempfin.2011.08.003

Cheung, A. (2011). Do Stock Investors Value Corporate Sustainability? Evidence from an Event Study. Journal of Business Ethics, 99(2), 145-165. https://doi.org/10.1007/s10551-010-0646-3

Kruger, P. (2015). Corporate goodness and shareholder wealth. Journal of Financial Economics, 115(2), 304-329. https://doi.org/10.1016/j.jfineco.2014.09.008

Lii, Y., \& Lee, M. (2012). Doing Right Leads to Doing Well: When the Type of CSR and Reputation Interact to Affect Consumer Evaluations of the Firm. Journal of Business Ethics, 105(1), 69-81. https://doi.org/10.1007/s10551-0110948-0

Luo, X., \& Bhattacharya, C. B. (2006). Corporate social responsibility, customer satisfaction, and market value. Journal of Marketing, 70(4), 1-18. https://doi.org/10.1509/jmkg.70.4.001

Luthans, B. C., \& Sommer, S. M. (1999). The impact of downsizing on workplace attitudes: Differing reactions of managers and staff in a health care organization. Group \& Organization Management, 24(1), 46-70. https://doi.org/10.1177/1059601199241004

MacKinley, A. (1997). Event studies in economics and finance. Journal of Economic Literature, 35(1), 13-39. Retrieved from www.jstor.org/stable/2729691

McWilliams, A., Siegel, D., \& Teoh, S. H. (1999). Issues in the Use of the Event Study Methodology: A Critical Analysis of Corporate Social Responsibility Studies. Organizational Research Methods, 2(4), 340-365. https://doi.org/10.1177/109442819924002

Mulherin, J. H., \& Boone, A. L. (2000). Comparing acquisitions and divestitures. Journal of Corporate Finance, 6(2), 117139. https://doi.org/10.2139/ssrn.218145 
Nakai, M., Yamaguchi, K., \& Takeuchi, K. (2013). Sustainability membership and stock price: An empirical study using the Morningstar-SRI Index. Applied Financial Economics, 23 (1), 71-77. https://doi.org/10.1080/09603 107.2012.709602

Peress, J. (2014). The media and the diffusion of information in financial markets: evidence from newspapers strikes. Journal of Finance, 69(5), 2007-2043. https://doi.org/10.1111/jofi.12179

Phillips, R. A., \& Reichart, J. (2000). The environment as a stakeholder? A fairness-based approach. Journal of Business Ethics, 23, 185-197. https://doi.org/10.1023/A:1006041929249

Przychodzen, J., Gomez-Bezares, F., Przychodzen, W., \& Larreina, M. (2016). ESG issues among fund managers-factors and motives. Sustainability, 8(10), 1078. https://doi.org/10.3390/su8101078

Sampath, V. S., Gardberg N. A., \& Rahman, N. (2018). Corporate Reputation's Invisible Hand: Bribery, Rational Choice, and Market Penalties. Journal of Business Ethics, 151(3), 743-760. https://doi.org/10.1007/s10551-016-3242-3

Starik, M. (1995). Should trees have managerial standing? Toward stakeholder status for non-human nature. Journal of Business Ethics, 14, 207-217 (1995). https://doi.org/10.1007/BF00881435

United Nations Secretary General (UN). (2019). Roadmap for Financing the 2030 Agenda for Sustainable Development: 2019-2020. Retrieved from https://www.un.org/sustainabledevelopment/wp-content/uploads/2019/07/UN-SGRoadmap-Financing-the-SDGs-July-2019.pdf

Waddock, S. A., \& Graves, S. B. (1997). The corporate social performance-financial performance link. Strategic Management Journal, 18 (4), 303-319. https://doi.org/10.1002/(SICI)1097-0266(199704)18:4<303::AID-SMJ 869>3.0.CO;2-G

Worrell, D. L., Davidson, W. N., \& Sharma, V. M. (1991). Layoff Announcements and Stockholder Wealth. Academy of Management Journal, 34(3), 662-678. https://doi.org/10.5465/256410

Virvilaite, R., \& Daubaraite, U. (2011). Corporate Social Responsibility in Forming Corporate Image. Inzinerine Ekonomika-Engineering Economics, 22(5), 534-543. https://doi.org/10.5755/j01.ee.22.5.972

Xu, X. D., Zeng, S. X., \& Tam, C. M. (2012). Stock Market's Reaction to Disclosure of Environmental Violations: Evidence from China. Journal of Business Ethics, 107(2), 227-237. https://doi.org/10.1007/s10551-011-1035-2

Van Duuren, E., Plantinga, A., \& Scholtens, B. (2016). ESG Integration and the Investment Management Process: Fundamental Investing Reinvented. Journal of Business Ethics, 138(3), 525-533. https://doi.org/10.1007/s10551-0152610-8

Yoon, Y., Gurhan-Canli, Z., \& Schwarz, N. (2006). The Effect of Corporate Social Responsibility (CSR) Activities on Companies With Bad Reputations. Journal of Consumer Psychology, 16(4), 377-390. https://doi.org/10.1207 /s15327663jcp1604_9

\section{Authors' biographies}

Anna Dziadkowiec is a PhD candidate at Wroclaw University of Economics and Business at the Department of Corporate and Public Finance. Research field: corporate sustainability performance and its relation with value creation for stakeholders.

Karolina Daszynska-Żygadlo $\mathrm{PhD}$, is an Assistant Professor at Wroclaw University of Economics and Business (Poland) at the Department of Corporate and Public Finance. She received her PhD from Wroclaw University of Economics and Business in the field of finance. She has been involved in various research projects in the topic of sustainability and financing of renewable energy investments. Research field: corporate finance and corporate sustainability, sustainable finance instruments.

The article has been reviewed.

Received in February 2020; accepted in April 2021.

This article is an Open Access article distributed under the terms and conditions of the Creative Commons Attribution 4.0 (CC BY 4.0) License (http://creativecommons.org/licenses/by/4.0/). 